地域在住高齢者の食行動のセルフエフィカシーと 食物摂取状況との関連

千歳 万里 ${ }^{*} \cdot$ 田中 あゆ子 ${ }^{* *} \cdot$ 北山 由起子** ·加藤 則子**

（*神戸松蒢女子学院大学，**国立保健医療科学院）

\title{
Relationship between self-efficacy of dietary behavior and food intake of community-dwelling elderly people.
}

\author{
Mari Chitose *, Ayuko Tanaka**, Yukiko Kitayama **, Noriko Kato ** \\ * Kobe Shoin Women's University, 1-2-1, Shinohara Obonoyama-cho Nada-ku, Kobe, 657-0015 \\ ** National Institute of Public Health, 2-3-6, Minami Wako, Saitama, 351-0197 \\ * \% 657-0015 神戸市灘区篠原伯母野山町 1-2-1

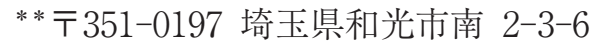

Recently, nutritional education has made the transition to an education that encourages the practice and continuance of adequate eating behaviors based on theory of behavioral science. The purpose of this study is to clarify the relationship between the self-efficacy of the eating behavior and food intake in order to examine the ideal method of nutritional education that is desirable for the elderly.

We conducted a self-administered questionnaire survey with 42 elderly people (mean 74. $9 \pm$ standard deviation 4.7 years old) on self-efficacy regarding dietary behavior and food intake. In order to reduce the burden of the subjects, and minimize its error, we calculated food intake based on one-day food records (dishes name or food name, and their approximate quantity).

The results are as follows.

1) Those who answered, "Yes, I can do this quite well" to the question of "use a nutrition label when buying food" were less than $15 \%$.

2) The intakes of all dish classifications were beyond these recommended dishes intake, especially fruits, milk and milk products, and snacks, confectionery and beverages far exceeded them.

3) No relationship was observed between all the self-efficacy items except for one item: "eat many vegetables" and the food intake situation.

4) For the optimum intake group of vegetable dishes and the nonoptimum intake group of milk and milk products, the ratio that these occupy in all the high groups of self-efficacy items were high.

5) The high self-efficacy group and high nutrition awareness group involved inadequate (excessive) milk and milk products intake.

6) The results, which were classified by the type of household, the high self-efficacy group of "eat many vegetables" and "limit the intake of fatty and greasy foods" and the optimum intake group of vegetable dishes, those of multiple generation households were significantly low compared with the one-person and married couple households.

These results suggest that the indices development that measures properly the self- 
efficacy of the dietary behavior of elderly people is required. Moreover, it is required to create the opportunity for nutrition education for the elderly people, because they may have the knowledge of desirable food intake, which was lacking or mistaken. The education needs to teach how to take snacks appropriately and utilize nutrition labeling, and to involve their families and the person in charge of cooking.

\section{I はじめに}

近年, 日本に扔ける栄養教育は, 集団を対象に知識を 普及する従来の型から，個人を対象に望ましい食行動の 実践及び継続への支援・促進を重視するようになった11。 行動科学の理論に基づいた教育・指導を導入し2)，2009 年 4 月より開始された特定健康診查・特定保健指導に㧈 いても，これに則した指導の徹底が求められている。

行動科学の理論において, セルフエフィカシーは行動 の変容ステージとともに変化し，行動の変容を予測する 重要な要因とされている ${ }^{3)}$ 。そのため, 食行動に関する 研究に拀いても, セルフエフィカシーの尺度開発4)-7), セルフエフィカシーを指標とした教育効果の測定 ${ }^{4), 5}$, 8) 10) セルフエフィカシーと食行動や食物摂取との関係 ${ }^{4), 11}$ な ど様々な報告がされている。しかし，高齢者を対象にし た研究は少なく, セルフエフィカシーを指標に教育効果 を測定した研究12) やセルフエフィカシーと食行動の関倸 ${ }^{13)}$ などの報告を除いては見当たらない。そこで，本研究で は, 高齢者の食行動のセルフエフィカシーと食物摂取状 況との関係を明らかにし, 高齢者へのより良い栄養教 育・指導のあり方について検討を行った。

\section{II 研究方法}

\section{1. 対 象 者}

愛知県 $\mathrm{H}$ 市に在住する65歳以上の高齢者で, 同地域に 所在する特定非営利活動法人総合型地域スポーツクラブ が介護予防を目的に実施するシニア元気カアップ・ス テーション運動教室の参加者 42 名 (女性 35 名, 男性 7 名) を対象とした。対象者の年齢は, 平均 $74.9 \pm$ 標準偏差 4.7歳（女性平均78.8 標準偏差4.9歳, 男性平均 $73.8 \pm$ 標準偏差4.2歳), 世帯は, 対象者のみの独居世帯 8 名 (19.0\%)，対象者を含む夫婦世帯15名（35.7\%），対象 者を含む多世代同居世帯19名（45.2\%）であった。

\section{2. 調查内容}

食行動に関するセルフエフィカシー及び食物摂取状況 について, 自記式質問紙による調査を行った。

\section{（1）食行動のセルフエフィカシー}

武見 ${ }^{4)}$ の望ましい食行動のセルフエフィカシーの項目 を参考に,「朝食を毎日食べる」,「腹八分目に抑える」,「栄 養のバランスを考えて食べる」,「野菜をたくさん食べる」, 「油脂や油っぽい料理を控える」,「食品購入時に栄養成 分表示を利用する」,「ゆっくり食べる」の 7 項目の質問 に対し，「かなりできる」、「少しできる」，「あまりでき ない」の3つの選択肢で尋ねた。

\section{（2）食物摂取状況}

高齢である対象者の負担とこれに伴う過誤に配慮し， 1 日分の食事記録による調查を行った。記録期間は2009 年 4 月中旬から 2009 年 5 月中旬までとし，同期間中の 日・祝日及び日常と異なる食生活（来客, 旅行など）の 日を除く任意の 1 日の朝・昼・夕食及び間食の記録をお 願いした。記録内容は，食事バランスガイド ${ }^{13)}$ の料理区 分（主食，副菜，主菜，牛乳・乳製品，果物）ごとの料 理名または食品名及びその概量，菓子の料理名または食 品名及びその概量, 嗜好飲料については, 記録日から遡 る 1 ケ月間の食品名及びその頻度と 1 回分の概量である。 対象者には, 食事バランスガイドの料理例を参考に記入 方法の説明を行った。ただし, 概量については,「つ (SV)」 の単位での記録を困難とする対象者が多かったため，食 事バランスガイドの料理例を用い通常の単位（「枚」や 「杯」等）での記録とその補足（器の大きさや盛り付け 量等）をお願いした。

\section{（3）食意識}

「食生活で気を付けていることはあるか」の質問に対し， 「はい」,「いいえ」の 2 つの選択肢で尋ね,「はい」と回 答した者に，その内容を自由回答法により質問を行った。 また，食生活で気になることについて自由回答法により 質問を行った。

\section{（4）肥満・栄養状態}

身長，体重，腹囲，体脂肪率の計測を行い，身長及び 体重から BMI（Body Mass Index）を算出した。なお, 身長は YL-65S/ 株式会社ヤガミ，体重及び体脂肪率は DC-320/オムロン株式会社を用い計測を行った。

\section{3. 分析方法}

年齢，BMI，腹囲，体脂肪率は平均と標準偏差を算出 した。食物摄取状況は, 料理区分ごとの食物摂取数及び 食物摂取懸隔を算出し, 料理区分間での比較及び相関関 係の分析を行った。な拉，食物摂取数は，食事記録を食 事バランスガイド ${ }^{14)}$ の料理区分ごとの料理・食品のサー ビングサイズに照らし合わせて算出した。菓子及び墸好 飲料は100kcal をサービングサイズとして算出し，それ

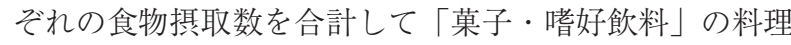
区分として算出した。食事バランスガイドの年齢別・料 理区分別摂取目安サービング数及び菓子・莻好飲料は 0.0 から 2.0 までを摂取目安サービング数として各対象の 食物摂取目安を算出した。食物摂取懸隔は, 対象ごとの 食物摂取目安と先述の食物摂取数との差から算出した。

食行動のセルフエフィカシーと食物摂取状況との関係 については, 食行動のセルフエフィカシー各項目の質問 
に対し「かなりできる」と回答した者を SE 高群，それ 以外の「少しできる」，「あまりできない」と回答した者 を SE 低群に分類し, 食物摂取状況は食物摂取数の目安 内を適正群，目安外を非適正群に分類し分析を行った。 食意識については，「食生活で気を付けていることはあ るか」の質問に対し「はい」と回答した者を意識高群,「い いえ」と回答した者を意識低群に分類し両者の食物摂取 懸隔を比較した。また，世帯の種類（独居世帯，夫婦世 帯，多世代同居世帯）と食物摂取状況及び食行動のセル フエフィカシーとの関連について分析を行った。

解析は，統計ソフト JMP7. 0.1（SAS Institute Inc., Cary, NC，USA）を用いた。正規性は Shapiro-Wilkの検定を 等分散性は両側 $\mathrm{F}$ 検定を用いた。肥満・栄養状態の男女 間の比較は Welchの $\mathrm{t}$-検定, 食物摂取数及び食物摂取 懸隔の料理区分間の比較は対応のある Student の $\mathrm{t}$-検定 食物摂取懸隔の料理区分間の関連は Spearmanの順位相 関を用いた。また，食行動のセルフエフィカシーと食物 摂取状況の関連は Fisherの正確確率検定を，食意識の 意識高群と意識低群の食物摂取懸隔の比較には Wilcoxon の順位和検定を用いた。食行動のセルフエフィカシー の SE 高群と SE 低群の割合の検定，世帯の種類と食物 摂取状況及び食行動のセルフエフィカシーの関連には尤 度比カイ 2 乗検定を用いた。いずれも $5 \%$ 未満を統計的 有意水準として有意性の検定を行った。

\section{4. 倫理的配慮}

全ての対象者に対し，本研究の目的，内容，方法，結 果の守秘及び個人情報の管理について書面により説明を 行い，本人の自由意志のもと書面にて同意を得た。なお，
本研究は, 国立保健医療科学院の倫理審査の承認を受け て実施した。

\section{III 結果}

\section{1．肥満・栄養状態}

肥満・栄養状態を示す計測值を表 1 に示す。対象全体 では, BMI 平均 $22.4 \pm$ 標準偏差3.0, 腹囲平均85.6土標 準偏差7. $0 \mathrm{~cm}$, 体脂肪率平均 29.4 土標準偏差 $7.5 \%$ であっ た。男女を比較すると, 腹囲 $(\mathrm{p}<0.05)$, 体脂肪率 （p<0.01）は有意に女性が高かったが， BMI では男女間 に有意な差は認められなかった。

\section{2. 食行動のセルフエフィカシー}

食行動のセルフエフィカシーの各項目について, SE 高群と SE 低群の割合を図 1 に示す。SE 高群の割合が 高かった項目（※（）内の数值は高群の割合を示す）は, 「朝食を毎日食べる $(90.5 \%) 」, 「$ 野菜をたくさん食べる

表 1 対象者の年齢と肥満・栄養状態

\begin{tabular}{|c|c|c|c|c|}
\hline & $\begin{array}{c}\text { 女性 } \\
(\mathrm{n}=35)\end{array}$ & $\begin{array}{c}\begin{array}{c}\text { 男性 } \\
(\mathrm{n}=7)\end{array}\end{array}$ & $\begin{array}{c}\text { 合計 } \\
(\mathrm{n}=42)\end{array}$ & \\
\hline & Mean S.D. & Mean S.D. & Mean S.D. & $\mathrm{p}$ \\
\hline 年齢（歳） & $73.8 \pm 4.2$ & $78.8 \pm 4.9$ & $74.9 \pm 4.7$ & $*$ \\
\hline BMI $\left(\mathrm{kg} / \mathrm{m}^{2}\right)$ & $22.7 \pm 2.8$ & $20.9 \pm 3.5$ & $22.4 \pm 3.0$ & n.s. \\
\hline 腹囲 $(\mathrm{cm})$ & $86.5 \pm 7.1$ & $81.1 \pm 5.1$ & $85.6 \pm 7.0$ & $*$ \\
\hline 体脂肪率（\%) & $31.6 \pm 5.5$ & $18.4 \pm 6.8$ & $29.4 \pm 7.5$ & $* *$ \\
\hline
\end{tabular}

Mean：平均值, S.D：標準偏差

男女間の比較：Welch の $\mathrm{t}$-検定

有意性の検定： n.s. : not significant, * : p $<0.05, * *$ : p $<0.01$

表 2 料理区分別食物摂取数及び食物捸取懸隔

\begin{tabular}{|c|c|c|c|c|c|c|c|}
\hline & \multicolumn{7}{|c|}{ 料理区分 } \\
\hline & $\begin{array}{l}\text { 主食 } \\
\text { (SV) }\end{array}$ & $\begin{array}{l}\text { 副菜 } \\
\text { (SV) }\end{array}$ & $\begin{array}{l}\text { 主菜 } \\
\text { (SV) }\end{array}$ & $\begin{array}{l}\text { 牛乳 } \cdot \text { 乳製品 } \\
\quad(\mathrm{SV})\end{array}$ & $\begin{array}{l}\text { 果物 } \\
\text { (SV) }\end{array}$ & $\begin{array}{c}\text { 菓子 ·喏好飲料 } \\
(\mathrm{SV})\end{array}$ & \\
\hline & A & $\mathrm{B}$ & $\mathrm{C}$ & $\mathrm{D}$ & $\mathrm{E}$ & $\mathrm{F}$ & \\
\hline & Mean S.D. & Mean S.D. & Mean S.D. & Mean S.D. & Mean S.D. & Mean S.D. & $\mathrm{p}$ \\
\hline 食物摂取目安 ${ }^{a}$ & $\begin{array}{l}4.1 \pm 0.5 \\
? \\
5.3 \pm 0.9\end{array}$ & $\begin{array}{l}4.9 \pm 0.3 \\
? \\
5.9 \pm 0.3\end{array}$ & $\begin{array}{l}3.0 \pm 0.0 \\
\text { ? } \\
4.1 \pm 0.5\end{array}$ & $2.0 \pm 0.0$ & $2.0 \pm 0.0$ & $\begin{array}{l}0.0 \pm 0.0 \\
2.0 \pm 0.0\end{array}$ & \\
\hline 食物摂取数 b & $3.6 \pm 0.6$ & $3.7 \pm 1.4$ & $5.7 \pm 2.2$ & $3.1 \pm 1.3$ & $3.3 \pm 1.9$ & 3. $0 \pm 1.4$ & $\begin{array}{l}\mathrm{A}<\mathrm{C}^{* *}, \mathrm{~A}>\mathrm{D}^{*}, \mathrm{~F}^{* * *} \\
\mathrm{~B}<\mathrm{C}^{* *}, \mathrm{~B}>\mathrm{D}^{*}, \mathrm{~F}^{*} \\
\mathrm{C}>\mathrm{D}^{* *}, \mathrm{E}^{* *}, \mathrm{~F}^{* *}\end{array}$ \\
\hline 食物摂取懸隔 c & $-0.6 \pm 0.6$ & $-1.4 \pm 1.3$ & $1.8 \pm 1.9$ & $1.1 \pm 1.3$ & $1.4 \pm 1.9$ & 1. $2 \pm 1.2$ & $\begin{array}{l}\mathrm{A}>\mathrm{B}^{* * *}, \mathrm{~A}<\mathrm{C}^{* *}, \mathrm{D}^{* *}, \\
\mathrm{E}^{* *}, \mathrm{~F}^{* *} \\
\mathrm{~B}<\mathrm{C}^{* * *}, \mathrm{D}^{* *}, \mathrm{E}^{* *}, \\
\mathrm{~F}^{* * *} \\
\mathrm{C}>\mathrm{D}^{* *}\end{array}$ \\
\hline
\end{tabular}

a主食，副菜，主菜，牛乳・乳製品，果物は食事バランスガイドの年齢別・料理区分別の摂取目安サービング数，菓子・喏好飲料 は0.0から 2.0 までを摂取目安サービング数とした

b主食, 副菜，主菜，牛乳・乳製品，果物は食事記録を食事バランスガイドの料理区分ごとの料理・食品のサービングサイズに照 らし合わせて算出し，菓子・喏好飲料は $100 \mathrm{kcal}$ をサービングサイズとして算出 “各対象の食物摂取目安内を基準として食物摂取数との差を算出 Mean：平均値, S.D：標準偏差

料理区分 (主食 $: \mathrm{A}$, 副菜 $: \mathrm{B}$, 主菜 $: \mathrm{C}$, 牛乳・乳製品 $: \mathrm{D}$, 果物 $: \mathrm{E}$, 菓子・莻好飲料 $: \mathrm{F}$ ) 間の比較 $:$ Student の $\mathrm{t}$-検定 (対応のある) 有意性の検定： $*$ : $\mathrm{p}<0.05, * *: \mathrm{p}<0.01$ 


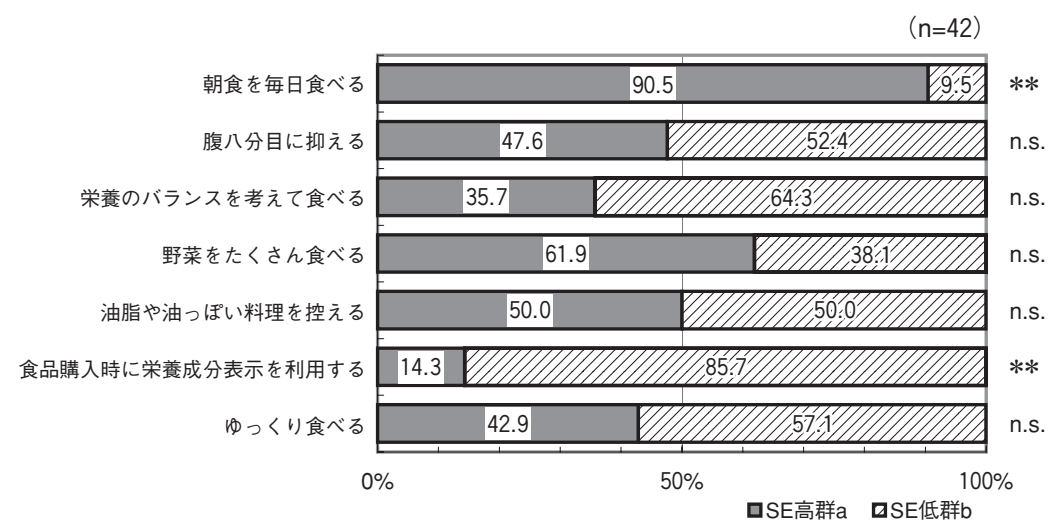

図 1 食行動のセルフエフィカシーの高群と低群の割合

a, b 食行動のセルフエフィカシーの各項目に拈いて「かなりできる」と回答した者を $\mathrm{SE}$ 高群, 「少しできる」または「あまりできない」と回答した者を SE 低群とした 数值は食行動のセルフエフィカシー各項目に占める $\mathrm{SE}$ 高群及び SE 低群の割合を示す $\mathrm{SE}$ 高群·SE 低群の割合 : 尤度比カイ 2 乗検定 有意性の検定： n.s. : not significant, $*$ : p $<0.05$

\section{表 3 料理区分間の食物摂取懸隔の相関}

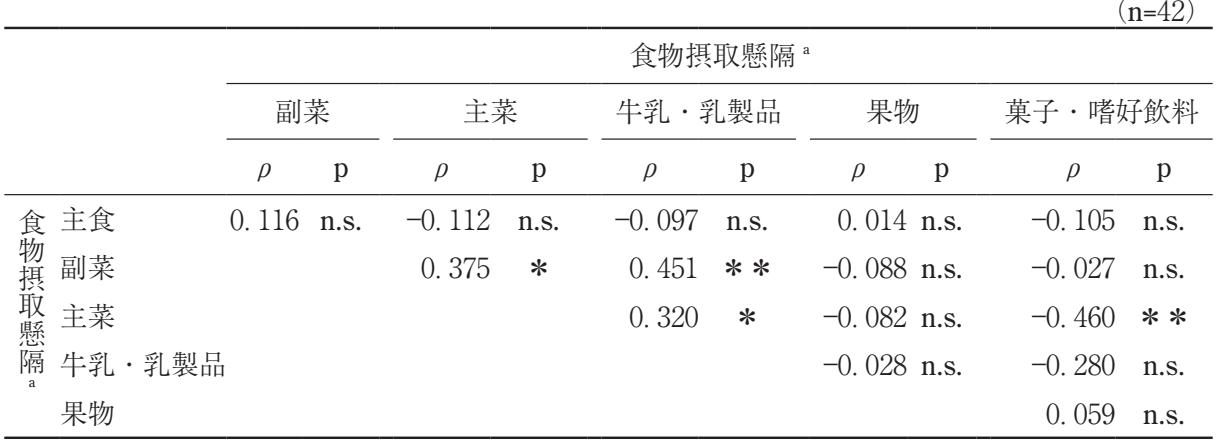

a主食, 副菜, 主菜, 牛乳・乳製品, 果物は食事バランスガイドの年齢別・料理区分別摂取目安サービング数を 基準として食物攝取数との差から算出, 菓子・嗜好飲料は 0.0 から 2.0 までを目安サービング数として算出 $\rho:$ Speaman の順位相関係数

有意性の検定： n.s.: not significant, $*$ : p $<0.05, * *$ : $<<0.01$

(61.9\%)」であり，反対に SE 低群の割合が高かった項 目は，「腹八分目に抑える $(47.6 \%) 」, 「 ゆ っ く り$ 食べる (42.9\%)」，「栄養のバランスを考えて食べる $(35.7 \%) 」$,

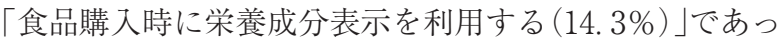
た。「油脂や油っぽい料理を控える $(50.0 \%) 」 の \mathrm{SE}$ 高 群と SE 低群の割合は等しかった。

\section{3. 食物摂取状況}

料理区分ごとの食物摂取目安, 食物摂取数, 食物摂取 懸隔の平均及び標準偏差を表 2 に示す。食物摂取数は高 い順に, 主菜 $5.7 \pm 2.2$, 副菜 $3.7 \pm 1.4$, 主食3. $6 \pm 0.6$, 果物 $3.3 \pm 1.9$, 牛乳・乳製品 $3.1 \pm 1.3$, 菓子 - 嗜好飲料 3. $0 \pm 1.4$ であった。次に，食物摂取懸隔をみると，食物 摂取目安より多かったものは，主菜1.8土1.9, 果物 1.4 \pm 1.9 ，菓子. 嗜好飲料 $1.2 \pm 1.2$ ，牛乳・乳製品 $1.1 \pm 1.3$, 食物摂取目安より少なかったものは, 副菜-1. $4 \pm 1.3$, 主食- $0.6 \pm 0.6$ であり，全ての料理区分の食物摂取が目 安外であった。

料理区分間の食物摂取数の比較を見ると，主菜は他の
すべての料理区分の食物摂取数に比べ有意に多く $(\mathrm{p}<0.01)$ ，主食及び副菜は牛乳・乳製品，菓子・嗜好飲 料と比べ有意に多かった $(\mathrm{p}<0.05, \mathrm{p}<0.01)$ 。次に, 食 物摂取懸隔の料理区分間での比較を見ると, 副菜は全て の料理区分に比べて有意に少なく（ $\mathrm{p}<0.01 ）$, 主食も副 菜以外の全ての料理区分に比べて有意に少なかった $(\mathrm{p}<0.01)$ 。また, 牛乳・乳製品は主菜に比べて有意に少 なかった（p<0.05）。

次に，料理区分間の食物摂取懸隔の相関を見ると（表 $3)$, 副菜と主菜 $(\rho=0.375, \mathrm{p}<0.05)$, 副菜と牛乳・乳 製品 $(\rho=0.451, \mathrm{p}<0.01)$ ，主菜と牛乳・乳製品（ $\rho$ $=0.320, \mathrm{p}<0.05 ）$ との間に有意な正の相関が見られた。 また，主菜と菓子・嗜好飲料には有意な負の相関（ $\rho=-$ 0.460, p<0.01）が見られた。

\section{4. 食行動のセルフェフィカシーと食物摂取状況}

料理区分ごとの食行動のセルフエフィカシーと食物摂 取状況との関連を表 4 に示す。なお, 食行動のセルフエ フィカシーの項目のうち「朝食を毎日食べる」は SE 低 
表 4 食行動のセルフエフィカシーと料理区分別食物摂取状況

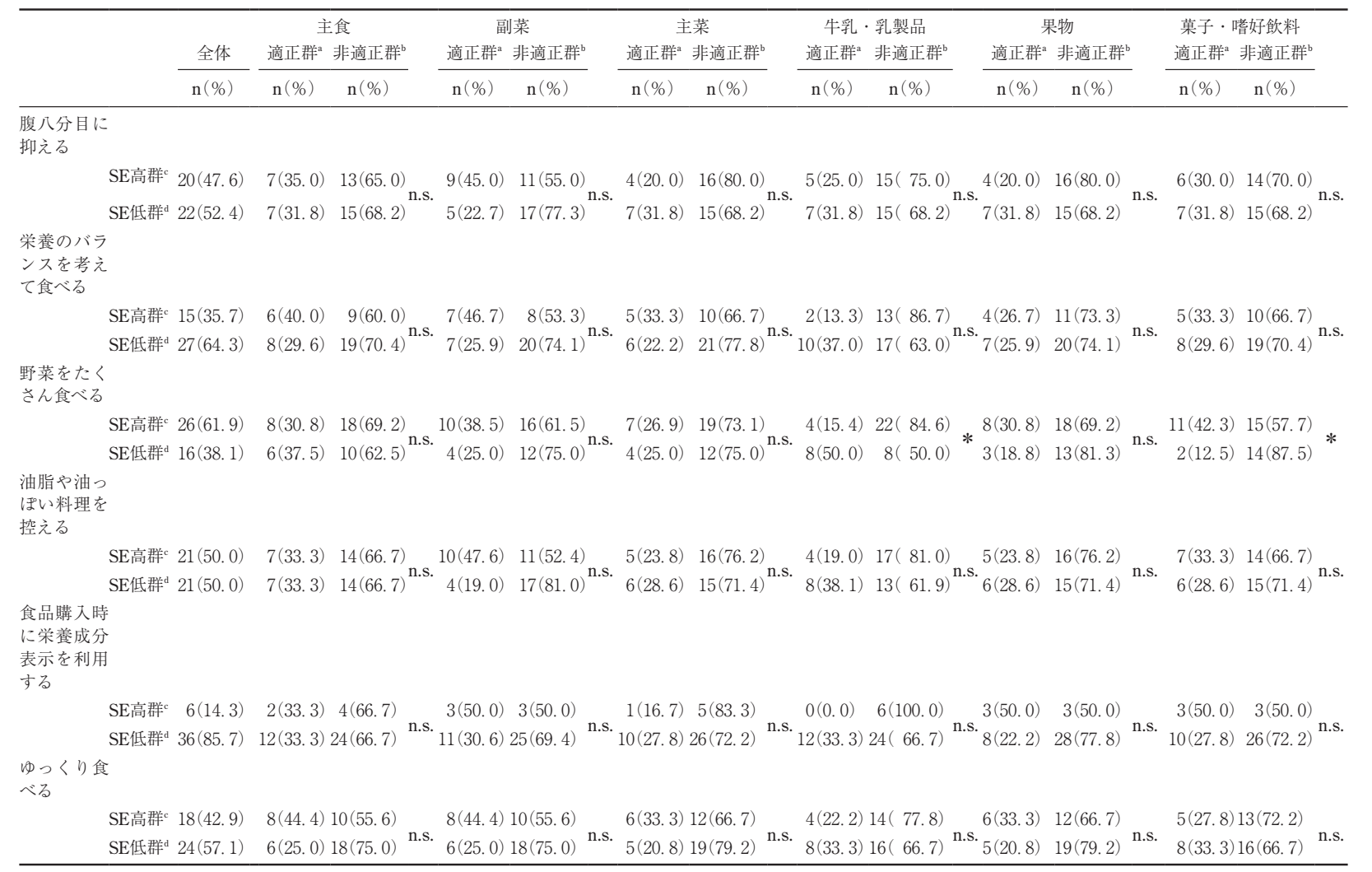

食行動のセルフエフィカシーと料理区分別の評価の関連性 : Fisher の正確確率検定

有意性の検定： n.s.: not significant, * $: \mathrm{p}<0.05$

$\mathrm{a}, \mathrm{b}$ 食物摂取数の目安内を適正群, 目安外を非適正群とした

c,d 食行動のセルフエフィカシーの各項目において「かなりできる」と回答した者をSE 高群,「少しできる」または「あまりできない」と回答した者をSE低群とした

群の該当者が少なかったため，同項目を除く 6 項目につ いての分析結果を報告する。

食行動のセルフエフィカシーの SE 高群に占める食物 摂取適正群の割合は非適正群に比べ高かった。とくに副 菜はすべての項目の SE 高群に占める適正群の割合が高 く，逆に牛乳・乳製品はすべての項目の SE 高群に占め る非適正群の割合が高かった。食行動のセルフエフィカ シーと食物摂取状況との間に有意な関連を認めたのは, 「野菜をたくさん食べる」の項目の牛乳・乳製品の摂取 $(\mathrm{p}<0.05)$ 及び菓子・嗜好飲料の摂取（ $\mathrm{p}<0.05 ） て ゙ あ り$, 他の項目では有意な関連は認めなかった。

\section{5. 食意識と食物摂取状況}

食意識の意識高群と意識低群の食物摂取懸隔の比較を 表 5 に示す。牛乳・乳製品を除く料理区分の食物摂取懸 隔は，意識高群と意識低群との間に有意な差は見られな かった。牛乳・乳製品の摂取懸隔の平均及び標準偏差は, 意識高群 $1.4 \pm 1.4$, 意識低群 $0.6 \pm 0.9$ であり，意識高群 の摂取懸隔が意識低群に比べ有意に多かった（ $\mathrm{p}<0.05 ） 。$ また,「食生活で気を付けていることはあるか」に対し「は い」と回答した30名（71.4\%）のうち，気を付けている 内容で多かったものは，「塩分を控える」10名（33.3\%）, 「脂肪を控える」10名（33.3\%)，「海藻・野菜を摂る」 9 名（30.0\%）であった。食生活で気になることについ
表 5 食意識と料理区分別食物摂取懸隔

\begin{tabular}{|c|c|c|c|c|}
\hline & $\begin{array}{c}{\text { 意識高群 }{ }^{\mathrm{b}}}_{(\mathrm{n}=30)}\end{array}$ & \multicolumn{2}{|l|}{$\begin{array}{c}{\text { 意識低群 }{ }^{\mathrm{c}}}_{(\mathrm{n}=12)}\end{array}$} \\
\hline & & Mean S.D. & Mean S.D. & $\mathrm{p}$ \\
\hline \multirow{6}{*}{ 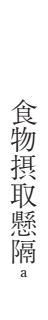 } & 主食 (SV) & $-0.7 \pm 0.7$ & $-0.4 \pm 0.3$ & n.s. \\
\hline & 副菜（SV） & $-1.5 \pm 1.3$ & $-1.2 \pm 1.1$ & n.s. \\
\hline & 主菜 (SV) & $1.9 \pm 1.9$ & $1.7 \pm 1.9$ & n.s. \\
\hline & 牛乳・乳製品（SV） & $1.4 \pm 1.4$ & $0.6 \pm 0.9$ & * \\
\hline & 果物（SV） & $1.2 \pm 1.8$ & $1.8 \pm 2.1$ & n.s. \\
\hline & 菓子・嗜好飲料 (SV) & $1.1 \pm 1.1$ & $1.4 \pm 1.5$ & n.s. \\
\hline
\end{tabular}

a主食, 副菜, 主菜, 牛乳・乳製品, 果物は食事バランスガイドの年齢 別・料理区分別摂取目安サービング数を基準として食物摂取数との差 から算出, 菓子・嗜好飲料は 0.0 から 2.0 までを目安サービング数とし て算出

b,c「食生活で気を付けていることはあるか」の質問に対し「はい」と回 答した者を意識高群「「いいえ」と回答した者を意識低群とした Mean：平均值, S.D：標準偏差

意識高群・低群の比較 : Wilcoxon の順位和検定 有意性の検定： n.s. : not significant, $*$ : p $<0.05$

て回答した者は16名（38.1\%）であり，その内容は，「間 食を摂りすぎてしまう」 3 名 $(18.8 \%), 「$ 食べ過ぎてし まう」3名（18.8\%），「孫の食事にあわせ油っぽい」 1 
表 6 世帯の種類と料理区分別食物摂取状況

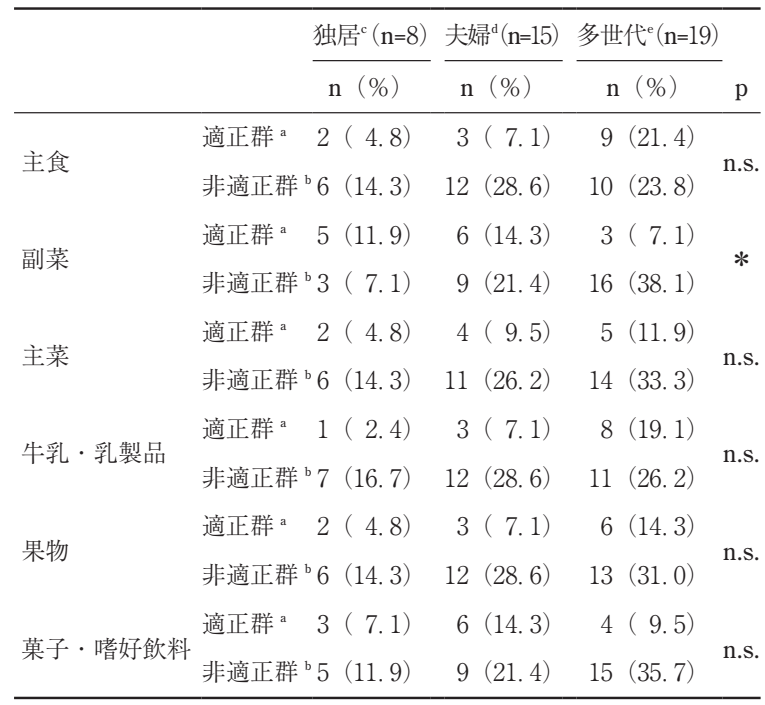

世帯の種類と料理区分別食物摂取状況の関連性 : 尤度比力イ2乗検定 尤度比カイ2乗検定の有意性： n.s.: not significant, $*$ : p $<0.05$

a,b 食物撖取数の目安内を適正群, 目安外を非適正群とした

c,d 対象者のみの独居世帯を「独居」, 対象者を含む夫婦世帯を「夫婦」, 対象者を含む多世代同居世帯を「多世代」とした

表 7 世帯の種類と食行動のセルフエフィカシー

\begin{tabular}{|c|c|c|c|c|c|}
\hline & & $\begin{array}{l}\text { 独居 }{ }^{\mathrm{C}} \\
(\mathrm{n}=8)\end{array}$ & $\begin{array}{c}\text { 夫婦 d }_{(\mathrm{n}=15)}\end{array}$ & $\begin{array}{l}\text { 多世代 } \\
(\mathrm{n}=19)\end{array}$ & \\
\hline & & $\mathrm{n}(\%)$ & $\mathrm{n}(\%)$ & n (\%) & $\mathrm{p}$ \\
\hline \multirow{2}{*}{ 腹八分目に抑える } & $\mathrm{SE}$ 高群a & $5(11.9)$ & $7(16.7)$ & $8(19.1)$ & \multirow{2}{*}{ n.s. } \\
\hline & $\mathrm{SE}$ 低群 ${ }^{b}$ & $3(7.1)$ & $8(19.1)$ & $11(26.2)$ & \\
\hline 栄養のバランスを考 & $\mathrm{SE}$ 高群 ${ }^{\mathrm{a}}$ & $4(9.5)$ & $6(14.3)$ & $5(11.9)$ & \multirow{2}{*}{ n.s. } \\
\hline えて食べる & $\mathrm{SE}$ 低群 ${ }^{\mathrm{b}}$ & $4(9.5)$ & $9(21.4)$ & $14(33.3)$ & \\
\hline 野菜をたくさん食べ & SE 高群a & $6(14.3)$ & $12(28.6)$ & $7(16.7)$ & \multirow{2}{*}{$*$} \\
\hline る & $\mathrm{SE}$ 低群 $\mathrm{b}$ & $2(4.8)$ & $3(7.1)$ & $12(28.6)$ & \\
\hline 油脂や油っぽい料理 & $\mathrm{SE}$ 高群a & $4(9.5)$ & $11(26.2)$ & $6(14.3)$ & \multirow{2}{*}{$*$} \\
\hline を控える & $\mathrm{SE}$ 低群 ${ }^{\mathrm{b}}$ & $4(9.5)$ & $4(9.5)$ & $13(31.0)$ & \\
\hline \multirow{2}{*}{$\begin{array}{l}\text { 食品購入時に栄養成 } \\
\text { 分表示を利用する }\end{array}$} & $\mathrm{SE}$ 高群 ${ }^{a}$ & $2(4.8)$ & $2(4.8)$ & $2(4.8)$ & \multirow[b]{2}{*}{ n.s. } \\
\hline & $\mathrm{SE}$ 低群 ${ }^{\mathrm{b}}$ & $6(14.3)$ & $13(31.0)$ & $17(40.5)$ & \\
\hline \multirow{2}{*}{ ゆっくり食べる } & $\mathrm{SE}$ 高群a & $4(9.5)$ & $8(19.1)$ & $6(14.3)$ & \multirow{2}{*}{ n.s. } \\
\hline & $\mathrm{SE}$ 低群 ${ }^{b}$ & $4(9.5)$ & $7(16.7)$ & $13(31.0)$ & \\
\hline
\end{tabular}

世帯の種類と食行動のセルフエフィカシーの関連性 : 尤度比カイ 2 乗検 定

有意性の検定： n.s. : not significant, $*$ : p $<0.05$

a,b 食行動のセルフエフィカシーの各項目において「かなりできる」と回 答した者を SE 高群，「少しできる」または「あまりできない」と回答 した者を SE 低群とした

$\mathrm{c}, \mathrm{d}$ 対象者のみの独居世帯を「独居」, 対象者を含む夫婦世帯を「夫婦」, 対象者を含む多世代同居世帯を「多世代」とした
名（6.3\%）などであった。

6.世帯の種類と食物摂取状況及び食行動のセルフェ フィカシー

世帯の種類と食物摂取状況及び食行動のセルフエフィ カシーの関連の結果を表 6,7 に示す。なお, 食行動の セルフエフィカシーの項目は, 前項と同様「朝食を毎日 食べる」の SE 低群の該当者が少なかったため, 本項に おいても同項目を除く 6 項目についての分析結果を報告 する。

世帯の種類と食物攝取状況は, 副菜を除く他の料理区 分との間に関連は見られなかった。副菜の摂取は, 多世 代同居世帯に占める非適正群の割合が $38.1 \%$, 夫婦世 帯 $21.4 \%$ ，独居世帯 $7.1 \%$ に比べ有意に高かった $(\mathrm{p}<0.05)$ 。次に, 世帯の種類と食行動のセルフエフィカ シーとの関連を見ると，「野菜をたくさん食べる」は， 多世代同居世帯に占める SE 低群の割合が $28.6 \%$ と, 夫 婦世帯 $7.1 \%$, 独居世帯 $4.8 \%$ に比べ有意に高く $(\mathrm{p}<0.05)$ ，「油脂や油っぽい料理を控える」は，多世代 同居世帯に占める SE 低群の割合が $31.0 \%$ と，夫婦世帯 $9.5 \%$ ，独居世帯 $9.5 \%$ に比べ有意に高かった（ $<<0.05 ） 。$ 他の項目では世帯の種類との間に関連は見られなかった。

\section{$\mathrm{IV}$ 考察}

本研究では，食事バランスガイドを用いた料理区分ご との料理名または食品名及びその概量から食物摂取数を 求める食事調査を行った。予備調査では, 半定量型食物 摂取頻度調査 ${ }^{15)}$ を試みたが， 1 週間の摂取回数を思い出 すことを困難とする対象者が多く, 対象者の負担とこれ に伴う過誤を抑えることに重点を置き，大まかな食物摂 取状況を把握する目的で, 1 日分の食事記録による調査 を用いた。高齢者を対象にした食事調査は高齢者の特性 を十分理解し行う必要がある16) 19) が, 食事調査にかかる 負担とそれに伴う過誤を抑え, 且つ, 精度の高い調査を 行うことは非常に難しい。しかし，高齢化が進む中，こ れに応える調査法の開発は今後ますます重要になると考 察した。一方, 本研究において, 食行動のセルフエフィ カシーと食物摂取状況との関連について，「野菜をたく さん食べる」の 1 項目を除いて有意な関連が見られな かったことから, 高齢者の食行動のセルフエフィカシー を適切に測る尺度の開発も必要と考察した。また，本研 究では, 男女比が大きく異なる (男性対象者数が少ない) ため，男女間の相違を比較，検討するに至らなかったが， 今後は男女間の比較, 男女それぞれの特徴についても研 究を進める必要がある。

次に，食物摂取状況について，本研究ではすべての料 理区分の食物摂取数が食物摂取目安外となりバランスを 欠く結果となった。とくに, 果物, 牛乳・乳製品, 菓子. 嗜好飲料は食物摂取目安を大きく上回った。菓子・嗜好 飲料は, 食事バランスガイドにおいて食事評価の対象外 として摂取上限を示しているだけである。しかし，本研 
究対象者全員が間食を摂っていたことから，実際に多く の高齢者が間食を摂っていることが推察され，間食の摂 り方（回数や量, タイミングなど）やより良い食品の例 示など，適切な摂取を促すための啓発も必要と考察した。 ただし，食生活を営む目的は，健康・栄養状態の維持の みならず QOL の維持向上も重要であり, それを損なわ ないよう留意した指導でなくてはならない。また，「食 品購入時に栄養成分表示を利用する」の質問に対し,「か なりできる」と回答した者は15\%に満たず，栄養成分表 示の改良, あるいは, 活用方法についての教育も必要と 考察した。

Banduraは，セルフエフィカシーの強い個人や集団は, 望ましい適応や自己変革に向けて意欲を強化し行動を発 動させる ${ }^{20)}$ と述べている。本研究において, 食行動のセ ルフエフィカシーと食物摂取状況の間に有意な関連を認 めたのは「野菜をたくさん食べる」の 1 項目だけであっ たが，食行動のセルフエフィカシーのすべての項目にお いて, 副菜の摂取適正群及び牛乳・乳製品の非適正群が $\mathrm{SE}$ 高群に占める割合が高かったことから，食行動のセ ルフエフィカシーと食物摂取状況の間に何らかの関連が あると推察される。また, 食行動のセルフエフィカシー が高く食意識も高い群で牛乳・乳製品の摂取が非適正 (過剩)であった背景には, 食知識の欠如, あるいは, 誤っ た食知識があるものと推察され，料理区分別の食知識や 食物摂取に対する意識について更なる検討が必要である と考察した。高齢者は食事に関する認識が浅く日々の食 生活を自身の好みで営んでいることが多く ${ }^{16)}$, 間違った 食行動を訂正するのは困難 ${ }^{21)}$ とする報告もあるが，個々 の対象者が食を営む力を形成した時期の食環境や栄養教 育について併せて検討を行う必要がある。また，主食や 副菜など食物摂取数が目安を下回ったものについては, 食行動のセルフエフィカシー, 食知識, 食意識だけでな く, 加齢に伴う食物摂取減少と併せた検討が必要と考察 した。

先行研究において, 多世代同居の調理者は高齢者の好 む食事を作ることに配慮や工夫をしているが高齢者は不 満を感じている ${ }^{22)}$ とされている。本研究においても, 多 世代同居世帯では独居世帯及び夫婦世帯に比べ，「野菜 をたくさん食べる」,「油脂や油っぽい料理を控える」の 食行動のセルフエフィカシーが有意に低く, 副菜の摂取 の適正群も有意に低く，更に，多世代同居世帯の高齢者 から,「孫の食事にあわせ油っぽい」「食べ過ぎてしまう」 などの意見が見られた。これらのことから，高齢者への 栄養教育は，高齢者本人たけでなく，その家族や調理者 を巻き込んだ教育機会の創出が必要と考察した。

\section{$\mathrm{V}$ 要 約}

近年, 栄養教育は行動科学の理論に基づいた, 適切な 食行動の実践と継続を促す教育へと変遷してきた。本研 究の目的は, 高齢者への望ましい栄養教育のあり方を検
討するため, 食行動のセルフエフィカシーと食物摂取状 況との関係を明らかにすることである。

高齢者 42 名 (平均年齢 $74.9 \pm$ 標準偏差 4.7 歳) を対象に, 食行動のセルフエフィカシー及び食物摂取状況について 自記式質問紙による調査を行った。高齢である対象者の 負担とこれに伴う過誤を最小限に抑えるため, 食物摂取 状況は 1 日分の食事記録（料理名や食品名とその概量）

にて算出した。

その結果は以下の通りである。

1）「食品購入時に栄養成分表示を利用する」の質問 に対し，「かなりできる」と回答した者は $15 \%$ に満 たなかった。

2）食物摂取状況は，全ての料理区分において食物 摂取目安外であった。とくに，果物，牛乳・乳製品， 菓子・嗜好飲料は摂取目安を大きく上回った。

3）食行動のセルフエフィカシーについては,「野菜 をたくさん食べる」の 1 項目を除いて食物摂取状 況との間に有意な関連が見られなかった。

4 ）副菜の摂取適正群及び牛乳・乳製品の非適正群 は, 食行動のセルフエフィカシーのすべての項目 の SE 高群に占める割合が高かった。

5 ）食行動のセルフエフィカシーが高く食意識も高 い群は, 牛乳・乳製品の摂取が非適正(過剩)であっ た。

6 ）多世代同居世帯は独居世帯及び夫婦世帯に比べ, 「野菜をたくさん食べる」，「油脂や油っぽい料理を 控える」の食行動のセルフエフィカシーが有意に 低く, 副菜の摂取の適正群に占める割合も有意に 低かった。

以上の結果より，高齢者の食行動のセルフエフィカ シーを適切に測る尺度開発が必要であると考察した。ま た，高齢者は食知識が欠如または䛊った食知識を有する 可能性があるため, 高齢者への栄養教育の機会を創出す る必要があり, その内容には間食の適切な摂取方法や栄 養成分表示の活用方法を盛り込み，また，高齢者本人だ けでなく，その家族や調理者を巻き込んだ教育が必要で あると考察した。

\section{文献}

1）健康日本21企画検討会 - 健康日本21計画策定検討会：21 世紀に打ける国民健康づくり運動（健康日本21）について 報告書, 健康・体力づくり事業財団（2000）

2 ) 武藤志貴子：食行動変容段階と食生活改善に関する消費 者ニーズと関連の Web アンケートによる検討, 栄養学雑誌, 61（1)，31-37 (2003)

3 ） 赤松利恵, 武見ゆかり：トランスセオレティカルモデル の栄養教育への適用に関する研究の動向, 日本健康教育誌 15 (1), 3-18 (2007)

4 ）武見ゆかり：厚生科学研究費補助金健康科学総合研究事 業「若年成人への栄養・食教育診断・評価指標に関する総 合的研究」平成10年度 12 年度総合報告書, 25-31（2001） 
5）武見ゆかり：若年成人への栄養・食教育の診断・評価の 指標に関する研究：食スキル・食態度・食行動面から, 栄 養学雑誌，60（3），131-136（2002）

6 ) Parcel, G. S., Edmundson, E., Perry, C. L., Feldman, H. A., O'Hara-Tompkins, N., Nadar, P. R., Johnson, C. C. and Stone, E. J.: Measurement of self-efficacy for diet-related behaviors among elementary school children, J. Sch. Health, 65 ( 1), 23-27 (1995)

7 ) Lechner, L. and De Vries, H.: Starting participation in an employee fitness program; attitudes, social influence, and selfefficacy, Prev. Med., 24 ( 6 ), 627-633 (1995)

8 ）赤松利恵，大竹恵子，島井哲志：減量における意思決定 バランス尺度と行動変容の段階一減量の意思決定バランス 尺度（D B I） 日本版作成と信頼性, 妥当性の検討一, 健 康心理学研究，16，1-9 (2003)

9）鈴木純子, 荒川義人, 大塚吉則, 安江千歳, 森谷絜：大 学生における行動変容段階別アプローチと Glycemic Index （GI）を用いた栄養教育の検討，栄養学雑誌，64（1），2129 (2006)

10）森谷絜：「健康のための行動変容」における「健康行動理 論」の有用性の検討 (総説), 天使大学紀要， 7, 1-14 (2007)

11）柴英里, 森敏昭：トランスセオレティカル・モデルにお ける行動変容ステージから見た大学生の食生活の実態, 日 本食生活学会誌，20（1），33-41（2009）

12）松下佳代，足立己幸：高齢男性に対する実物大料理カー ドを用いた栄養教育の有効性に関する研究, 栄養学雑誌, 58 ( 3 ), 109-124 (2000)

13）柴辻里香, 安酸史子：中高年女性の生活習慣改善に対す る自己効力と影響要因, 日本健康教育雑誌, 11（2）, 77-
91 (2003)

14）(社日本栄養士会監修 武見ゆかり, 吉池信男編：「食事バ ランスガイド」を活用した栄養教育・食育実践マニュアル， 第一出版，東京， 6-9 (2005)

15）吉村幸雄，高橋啓子：エクセル栄養君食物摂取頻度調査 FFQg Ver. 2. 0, 建帛社, 東京 (2008)

16）丸山智美，森田一三，中垣晴男：地域在宅高齢女性の食 事摂取調査一食事バランスガイドを用いた評価一，日本食 生活学会誌, 17（4），70-75（2007）

17）吉田繁子，元永恵子，小柏道子：高齢者を対象とした食 事調査に打けるポーションサイズの決定，栄養学雑誌，64 ( 3 ) , 189-193 (2006)

18）吉田繁子，元永恵子，奥井幸子，渡辺文子，香川幸次郎， 奥山真由美，北園明江，小柏道子：高齢者のための半定量 的食物摂取頻度調查法の試作, 近畿福祉大学紀要, 3 (1), 29-41 (2002)

19）津村有紀，萩布智恵，広田直子, 曽根良昭：食品摂取状 況からみた高齢者の食生活, 生活科学研究誌, 3,47-54(2004)

20) Bandura, A. (Edit.) : Self-efficacy in changing societies, Cambridge University Press, New York (1995）（本明寛, 野 口京子監訳：激動社会の中の自己効力，金子書房（1997))

21）系井亜弥, 奥野直, 森本武利, 木村みさか：高齢者の活 動量と栄養摂取に関する調査（第 2 報：都市部高層住宅に 居住する高齢者に招ける夏期の調査結果），京都府立医科大 学医療技術短期大学紀要，11，211-221（2002）

22）瀬戸美江，塩谷知華，澤田崇子，藤本健四郎：世帯構成 の違いが高齢者の食生活に及ぼす影響, 日本調理科学会誌, 40（1）, 15-21 (2007) 